\title{
Abolishing Time and History: Lazarus and the Possibility of Thinking Political Events Outside Time
}

\section{Antonio Calcagno}

Sylvain Lazarus, a theorist, anthropologist and political activist, is well known in French circles, but is not so well known in English-speaking ones. Lately, more attention is being paid to him because Alain Badiou, whose work is becoming better known around the world, has referred often to Lazarus' work as deeply influential, especially concerning Badiou's political work and his theory of naming developed in Logiques des mondes. Both Badiou and Lazarus assert that we must move away from thinking politics as a kind of managing of political problems. The "cash-value" and "short-term solution" pragmatic approach to politics, e.g., as advocated by Richard Rorty, fails to think politics. It simply provides solutions to everyday problems, but it fails to take into consideration the very system or political conditions that make such day to day affairs possible, namely, political events (Badiou) or modes of political thinking (Lazarus).

Generally, Lazarus is central for an understanding of what it is to think politics, especially as it relates to time. Lazarus, like Badiou, argues that politics is not only about action and events but also includes thought. Politics is a form of thought_-and philosophy can and must think politics. As it turns out, both thinkers maintain that the contemporary penury in politics is most evident in the fact that there is little thought about politics. Rather, there is always an emphasis on managing the affairs of the state, on expedient political decision-making, and on what has traditionally been called political economy. Implicit in 
these acts is a political philosophy based on capitalism and globalization, all postulated on a liberal philosophy of the individual with its emphasis on private property and wealth. This philosophy, however, remains unquestioned and its implications insufficiently mined.

Badiou and Lazarus try to think about what politics is. For Lazarus, employing what he calls an anthropology of the name ('anthropologie du nom), thinking itself is the locus of politics. For Badiou, thinking through the constitutive elements of the political event and their ordering in time in fidelity (ordination temporelle) yields a philosophy of politics or a meta-politics. Hence, one of the major differences between Badiou and Lazarus is that the latter believes that we can abolish the category of time in thinking politics, whereas the former maintains that time is coeval with both the event and thinking of politics. What I wish to argue here is that Lazarus's position does admit temporality in that it implies an internal sequencing in thought. Lazarus' thinking about politics as a kind of internal sequencing, therefore, can be seen to run parallel to Badiou's notion of fidelity as a temporal ordering in thought (understood through retrospective apprehension).

\section{Eliminating the Category of 'Time and the Name of Politics}

Lazarus starts with a given, namely, there is thought - ily a de la pensée. ${ }^{1} \mathrm{He}$ notes that thinking understood within the rubric of "intellectualities" (i.e., les intellectualités or things thought) means that thinking is inherently multiple. There is a multiplicity of intellectualities. This derives from the fact that there are people who think. Les gens pensent. There are many people who think, and intellectualities thought by many people can be inherently multiple. Each of these intellectualities, though, is singular. ${ }^{2}$ Furthermore, Lazarus wishes to draw a distinction between unity and singularity. Unity for Lazarus is an operation of defining or identifying an intellectuality with one fixed meaning. When people think this one intellectuality, they think it identically and in the same way semper et ubicumque. But for Lazarus, a multiplicity of thinkers ensures that thought is not identical. By claiming that a multiplicity of intellectualities does not necessarily lapse into a unity, Lazarus wishes to avoid the legacy of les grands récits of unity that have dominated traditional Western metaphysics. Moreover, there is nothing in this multiplicity to suggest that there is such a thing as a unity. There is, however, within each multiple intellectuality a singularity or uniqueness that does not make each singularity reducible to another. Singularity, therefore, can be seen as a principle of individuation that separates 
one thought from another, giving to each singularity its own unicity or uniqueness. A thought can have multiple contents, definitions or names, yet each of these is singular or unique. Thinking can become singular in this way because thinking articulates the unique, individuated content of the thought. This is why Lazarus describes thought as an indistinct certain. It is indistinct in that it is multiple and unnameable, that is, not absolutely definable. There is, however, also a certainty that stems from the singularity contained within each multiple thought. Though not absolutely unified, intellectual singularities can be thought consistently in that they are given to us or localized in a certain sequence or we can arrange them in such a sequence. ${ }^{3}$ As Lazarus remarks, "La pensée est pensable." We shall see how this plays out when we examine the historical mode of thought.

In order to think through the content of thought, Lazarus believes we must employ what he calls an anthropology of the name (l'anthropologie du nom) or a nominal anthropology. We can name, and therefore communicate, the singular contents of thought, simultaneously thinking through their implications, especially if we establish and arrange the contents of our intellectualities in diverse ways. In order to carry out such an arrangement or ordering we have to abolish the category of time, which is understood as an objectively historical sequencing of events. The shift here is a move away from a supposedly "scientific" establishing of an order of events, moving more toward an internal or purely subjective way of thinking about certain, distinct events as the mode of politics they reveal. It should be remarked here that Badiou speaks of an ordering or fidelity to events, but his order is temporal, whereas Lazarus' is non-temporal. Lazarus calls for an internal thinking of the subjective that does not temporalize or even subjectivate as is the case with Badiou's subjectivity. Each subjective intervention that causes an event for Badiou is temporalizing.

Let us try to give an example of how a Lazarusian nominal anthropology functions. First, we turn to a summary definition of what a nominal anthropology is:

Le caractère anthropologique de mon propos se joue sur la question du nom innomable. Le nom est innomable parce que c'est celui d'une singularité irréductible à autre chose qu'à elle même, tandis que toute nomination ouvre à une généralisation, à une typologie, ou à une polysémie manifestant l'existence d'une multiplicité hétérogène, qui dénient la singularité. La proposition est donc que le nom existe; entendons la singularité existe, mais on ne peut pas la nommer, 


\section{ANTONIO CALCAGNO}

seulement la saisir par ce qu'on verra être ses lieux. La pensée délivre des noms qui sont innomables mais qui peuvent être saisis par leurs lieux. Dans la formule "anthropologie du nom", le nom désigne en définitive la volonté d'appréhender la singularité sans la faire disparaître. ${ }^{5}$

We will use the example of May '68 in France. May '68 is intellectual because it is a thought that we experience in our interiority (il a lieu) and it is singular because it is not reducible to any other event in human history. Interiority is the primary, internal locus of human thought. Also, May '68 took place only once at a certain point in France. Il a eu lieu. It can be thought in two modes: historically and intellectually. It has a certain beginning and a certain end as an historical sequence of events. All historical events for Lazarus are marked by a certain temporal sequencing. They have a certain beginning and there is a certain lapsing (péremption). May ' 68 is not now in the sense that its singularity is not identical or reducible to the political events of May 2008. ${ }^{6}$ But at the same time that we can name this event as May '68, it remains unnameable because the event is subject to an internal, subjective sequencing that can make thinkable additional various ideas, thoughts, and even more sequencing and orderings. Unnameable means that an intellectual singularity cannot be defined or thought absolutely, like certain streams of philosophy and history claim, as having only certain fixed names or definitions and no other possible ones. Rather, definitions compete as they refer to different prescriptions on what exists. ${ }^{7}$ So long as multiplicity endures as a multiplicity, it keeps multiplying. This multiplication means that thought or intellectualities will continue to accrue. To name something absolutely is to fix its identity, which would ultimately stymie the flow of multiplicity. Hence, though May ' 68 is a singular event that we can name, we can never fix and delimit its definitions. The new contents, names or definitions that emerge may give to May ' 68 new and additional synonymous names. For example, Badiou and Lazarus may name May ' 68 a pivotal and significant moment in French history, but Lyotard ${ }^{8}$ and Ferry' may call May ' 68 a failure. Badiou sees in ' 68 an event that made politics concretely possible, and Lazarus sees it as an intellectual singularity that made political thought possible. But Lyotard criticizes the arrogant grand narrative of the intellectuals, and Ferry points to the lack of enduring evidence of any real dramatic change. For Ferry, May ' 68 was more self-serving for certain French intellectuals than revolutionary.

In other words, for Lazarus we can never define or fix one 
meaning to May ' 68 , for it will have a plethora of meanings for those who experienced May ' 68 , depending upon which side they found themselves on during the various uprisings, etc. Also, as history unfolds, the events will take on new contents or definitions because of the development of new events that impact our understanding of May '68. It is the loci of May '68 (i.e., the streets, universities and factories) that give us the means to identify or name a sequence of events "May "68". Historically, there are certain sequences of events that have happened and intellectually we can will to think about these events. They can also occupy a place within our subjective interiorities. When we try to think of the name "politics" that emerges from the singular event "May '68", various categories will also emerge. Such categories include: revolutionary politics, terror, subversive politics, civil disobedience, and a politics of violence. These categories are the generalizations that emerge when we think about politics operating, and because they can contain so many diverse contents and definitions, they are not absolutely definable or nameable; rather, as was said previously, various definitions compete because the possibility of adding new definitions and contents exists, intellectual singularities resist having fixed names. They are unnameable insofar as they have to leave room for potential new definitions and contents to emerge. Yet, they can be pointed to and named when we think the historical or intellectual events that culminated in May '68. The uniquely anthropological character of Lazarus' project lies in the fact that he wishes to ground his project within the interiority of the human subject, a subject that is itself an indistinct certain.

For Lazarus, categories can be named and identified but they cannot be absolutely defined. A category is defined by Lazarus as the way an intellectual singularity operates. This categorical way of operating is called a mode. ${ }^{10}$ Something in a singularity can be categorized or thought of as belonging to that singularity. That which singularizes a singularity operates or functions in a peculiar way; it has a mode of operating. For example, the French Revolution (1792-1794) for Lazarus, thought as an intellectual singularity, operates in many ways. Each way is unique and is a category belonging to the French Revolution. As we shall see later, thinking about the French Revolution and how it operates allow us to think in a singular way about a revolutionary mode of politics.

At this point, it would be useful to comment on the notion of "name" in Lazarus' thought. When someone thinks the name "politics", 


\section{ANTONIO CALCAGNO}

politics is a singular intellectuality, that is, it is a thought. Lazarus does not use the term "object" of thought because he wishes to avoid the legacy of essentializing or objectivizing notions of thought, thereby focusing on thought as an anthropological undertaking. One way politics can be thought is historically, and it is this that is most relevant for our project because it is here that the category of time emerges and is eventually abolished by Lazarus. ${ }^{11}$

A name identifies that which is thought in thought. A name is not given directly or by itself. A name comes to be given through the category of place or site. In other words, a name comes to be through a certain locus (le nom a lieu) or a having taken place (le nom a eu lieu). To say the name has a place is to say that it is localized in thought en intériorité. Likewise, a singularity may have taken place, in which case it is an historical singularity that can be thought en intériorité. The name itself is unnameable, but we can identify the unnameable name by its having taken place or through its locus. The unnameable recapitulates, in part, the Derridean notion of undecidability in that one can never know absolutely that which is "present" before us. Yet, for Lazarus, there is an identification of a locus of the name that is possible, something which would be undecidable for Derrida.

But what does it mean to say that a name is unnameable yet identifiable in that we know it consists (faire consister) of an intelligible content through its loci or lieux? Lazarus gives us a concrete example in the form of the French Revoluton. ${ }^{12}$ If one is to think politics as an intellectual singularity, it is a name only because it appears as consisting in and through its having taken place (il a eu lieu). We cannot define absolutely what politics is, but we can name or identify it in our thought. The sites or lieux where politics took place (les sans-culottes, Convention, etc.) may be thought or named as a revolutionary mode of politics. In this case the singularity could be thought as the French Revolution. Lazarus gives the example of the revolutionary mode of politics as concretised in the extended "taking place" of the French Revolution between 1792-94. When we examine the sans-culottes and the other elements that constitute the French Revolution, we see that these elements are the places or the loci that house the undefinable but identifiable name of the category "revolutionary politics". In other words, we understand or grasp what politics is in a certain historical mode not by thinking in abstracto, but through the actual having taken place of the events, conventions, personalities, etc. that constitute the French Revolution. If we are to think through the nature of 
revolutionary politics, we do so only through the places or loci where such thought is incarnated, namely, our subjective interiority. In thinking these singularities, we can identify but not define absolutely what a revolutionary politics would entail. As we shall see later, the revolutionary mode of politics will take on competing definitions for different historians, each historian lending to the name revolutionary politics various senses, which in itself is a political act on the part of the historian. This kind of thinking about historians and their historiographies will reveal certain singular or nameable definitions and contents of politics.

To recapitulate, if we are to think the name "politics" we can do so in two modes. First, we can think the name of "politics" as an intellectual singularity of thought that is localized en interiorité. In this sense, Lazarus speaks of politics as having a place (la politique a lieu). In other words, we can think of politics within our subjective interiority. But politics can also be thought in its historical mode. Politics has taken place in historical events and sequences. La politique a eu lieu. The fact that we can think of politics in an historical mode means that politics has a relation to the real. It is not merely intellectual, but our thought about politics stems from and is articulated through real historical events and sequences. ${ }^{13}$

\section{Time and Politics}

Time enters Lazarus' framework through the identification of an historical sequence. ${ }^{14} \mathrm{~A}$ certain delimitation happens within a historical sequence in that it begins and ends. When it begins and when it ends is always difficult to demarcate. There is an inherent ambiguity in precise dating. ${ }^{15}$ We know, for example, that within the sequence named the French Revolution, the following sequence is possible: Storming of the Bastille, execution of the King, Reign of Terror.

The beginning and ending of a sequence may be difficult to date, especially because we can continue to see the French Revolution as impacting political thought generaliter. Badiou develops this thought with his notion of fidelity. For it established the possibility of ideals that continue to have significant impact on French politics and Western politics in general, especially the nature and roles of revolution, their justifications, the possibility of democratic and freely elected governments, etc. But Lazarus gives us a clue to help us differentiate sequences from one another and within themselves. The name that is given to a certain sequence designates what is singular or peculiar to that named political thought. One could not claim that the French, 


\section{ANTONIO CALCAGNO}

Russian, Haitian and American "Revolutions" are identical and reducible to one another. ${ }^{16}$ These are all different names and possess different contents but all can be thought in terms of yielding some insight into the revolutionary mode of politics. It should be remarked here that for Lazarus revolution is a name that properly belongs to the sequence called French Revolution 1792-94; it denotes specific sites and intellectualities. The name "Revolution" is loosely applied to the events mentioned above. Distinguishing various sequences from one another helps in the determination of one sequence being distinct from or irreducible to another intellectual singularity that is experienced in an historical mode.

Lazarus turns to the historian Marc Bloch to prove his thesis that thinking politics in its historical mode as an intellectual singularity does not require the category of time. For Bloch time is central. ${ }^{17}$ Why does time emerge as a central category in relation to history? Time is central for Bloch because he sees history as emerging from the continuity and perpetual change that make human beings conscious of being in "their times (leurs temps)". ${ }^{18}$ In other words, the experience of living in certain times and being subject to the events and happenings of a certain time as opposed to another time makes people conscious of the centrality of the unfolding of time. History grants access to the possibility of investigating human beings "in their times."

Lazarus sees in Bloch a thinker who tries to give to the subjective its own priority, mindful of the fact that subjectivity is not a thing in itself. Subjectivity also depends on the exterior world for its content and its being. It is this turn toward the subjective or interior that permits Lazarus to see in Bloch a thinker who has a similar project to his nominal anthropology. Hence, Lazarus reads Bloch in order to show how his project corrects certain excesses of the Blochian project.

Lazarus takes up Bloch's text Apologie pour l'bistoire in order to discuss the problematic of the subjectivation of time. Bloch sees history in temporal terms in that it confronts people on two levels, namely, the subjective and objective. ${ }^{19}$ Objectively, human beings are in time. They are subject to a time flow that yields a certain experience of the past, present and future. History, objectively speaking, therefore, can be a study of the chronology of events. Subjectively, however, there is an internal experience of time that Bloch calls consciousness. We subjectively experience certain worldly structures in a temporal fashion. For example, our own inner experience of the unfolding of events in our lives is affected by our inner time consciousness. Some event that 
may have taken three days to unfold chronologically or objectively may be experienced internally as a shock or a sudden experience that came out of nowhere and seemingly had no tangible precursors. Rather than oppose subjective and objective time in a dualistic relationship, Bloch sees time as a multiple operator that gives us multiple senses of things. He describes time as the source of the heterogeneous multiplicity and polysemy of reality. Time is a multiple operator because it is experienced as a continuous flow, but within this flow one experiences changes. It is this flow and the punctuation of changes that causes experience and history to be experienced in a multiplicity of ways and within a multiplicity of meanings. ${ }^{20}$

Caesar conquering Gaul or Luther posting his theses may be experienced and reinvestigated in the study of history, but the flow and change of time operate on history in that we have a multiplicity of meanings. For example, how people reacted to Caesar and Luther when these events were taking place and how we react to them today are different and different meanings of the conquering of Gaul and the posting of the theses continue to evolve. In many ways, there is a resonance with the Derridean project in that both posit a constant differentiation of meanings, but the two thinkers diverge in that Derridean analysis ends with an undecidability, whereas Bloch claims that the historian can formalize and make present this heterogeneous multiplicity through her investigations. Time becomes a locus of distribution of multiple meanings. ${ }^{21}$

Bloch's project was unique, as Lazarus interprets him, because he broke away from strictly objectivist views of history and science as developed by Durkheim in that he tried to give an account of the subjective experience of reality as being open to historical analysis. But there is a contradiction in Bloch's project. On the one hand, Bloch is an historian and he sees in history the possibility of giving objective descriptions of reality. On the other hand, he wishes to turn to an investigation of human interiority and psychology, but he does not wish to employ the objectivist categories of the science of history stricto sensu..$^{22}$

How does Bloch resolve this seeming contradiction? In other words, how can Bloch claim to give to the historical reality of one's interior life its own immanent historical analysis? History becomes an investigation of the subjective from "within" and from the "outside", and therefore is a science of the "human being in time." ${ }^{23}$ Time becomes a category that allows one to cross the two realms of the subjective and 
objective, that is, the domain within the subject and the domain outside the subject. All of reality is experienced and scientifically analyzed through the medium of the human subject and the subject becomes the locus of two perspectives of itself, namely, the external and the internal. The problem of knowing the external "thing in itself" is dismissed in that Bloch turns to the subjective science of knowing historically what an external reality is as it is experienced subjectively and not as a thing in itself existing outside of the subject.

Bloch maintains that duration permits the historian to examine and conduct his or her science of history. The constant heterogeneous multiplicity that time gives as an operator can be seized and grasped through durations, permitting historical analysis of the subjective reality as experienced from within and from without. ${ }^{24}$ Duration, for Bloch, allows objects to stand before historical consciousness in order to be examined. Bloch's account is based on the simple human experience of an enduring object of consciousness and the possibility of its being known and studied.

Bloch has a fractured notion of time, according to Lazarus. It is both changing and continuous. ${ }^{25}$ It is this fractured notion of time that gives history its problems. Not only does the chronicling of historical events become problematic, but so do their historiographical interpretations. Bloch's account of a continuously differentiating sense of time would make accounting for a nameable singularity an impossibility. For Lazarus, a subjective consciousness experiences time as the unfolding of a multiplicity of names or definitions that are heterogeneous and yet, human consciousness also has the capacity to give logical and historical consistency to the subjective reality as it is experienced en intériorité. But logical consistency does not mean trying to unify absolutely these names, contents of thought, and definitions in an over-arching Unum, making them fixed or absolute. And neither does it mean creating grand narratives. Thinking is an intellectual process, and part of this process consists in making intellectual singularities intelligible. A logical consistency would produce an awareness that thought is both multiple and singular. In other words, logic would help us understand that there is a difference between the singular and the multiple. History as a science ${ }^{26}$, for Bloch, would have as its ideal the reporting and investigation of this heterogeneous multiplicity that is made apparent through the fractured sense of Blochian time. Duration would allow for such an investigation and reporting. But if time operates as constantly differentiating, the singular senses of history become 
impossible to seize in thought as an enduring intellectual singularity. ${ }^{27}$

If we were to accept Bloch's notion of history and how time is central in such a notion, an inconsistency emerges. If we truly end up with a constantly differentiating heterogeneous multiplicity, then any kind of scientific description of the multiplicity will be inherently inadequate because the flow of time would constantly differentiate each of our attempts to describe scientifically and historically what we have experienced. The radical differentiation or heterogeneity that Bloch calls for would necessarily make the presentation of any kind of scientific facts impossible. Of course, this is only true if we accept Bloch's view of science as objectifying and positivistic, striving to represent that eternal unity which underlies reality. ${ }^{28}$

Let us turn to a closer examination of the above-mentioned inconsistency. If time is seen as constantly differentiating and giving us a heterogeneous multiplicity, this implies that any kind of repetition of identical historical analyses would be impossible. Moreover, even if we experience duration, the duration itself consists of a time flow of enduring instants - a flow that is subject to the same kind of radical differentiation that Bloch sees as vital for his project. A duration does not stop time even though it claims to be able to extract singularities from time and bring forth an analysis of such enduring singularities. But the moment we allow something to "endure" is the moment that its being becomes other than what it is. The flow of time continues to differentiate the historical object we think we have made endure in consciousness. The duration obscures the new senses that are emerging through the differentiation of the time flow that conditions all of reality. For example, if we were to conduct an historical analysis of the Gulf War of 1991 in 1996, and if we were to claim that such an object can be studied because of the experience of its intelligibility in consciousness as an object of historical analysis, we are not making room for the fact that the heterogeneous multiplicity that operates on the historical object in continual time continues to differentiate the definitions or contents of the object. The Gulf War has become laced with many and varied definitions. Any kind of description given at a particular time will necessarily be inadequate as the Gulf War continues to unfold in time. In its unfolding, the heterogeneous multiplicity that is the operation of time renders any enduring historical analysis impossible, for the Gulf War as an intellectual political and historical singularity continues to play itself out. The polysemy of the Gulf War continues to unfold.

Not only do the scientific analyses of history made possible 


\section{ANTONIO CALCAGNO}

through durations come into question because they claim that the durations are metaphysically present, to borrow from Derrida, but the possibility of having any kind of science called history becomes questionable. If Bloch is to be believed and if time is described as an operation of heterogeneous multiplicity, then the attempt to adapt to the "lignes mêmes du réel" $"$ becomes questionable.

Lazarus avoids this problem by claiming that the category of time as an operation of heterogeneous multiplicity must be eliminated because of the inconsistencies it brings to the fore. Lazarus believes that time in the Blochian sense is not necessary. Apart from the inconsistencies of Bloch's position, Lazarus maintains that if we were to return to thought itself and its subjective interiority, we can analyze historical and political singularities not only by naming them as does Bloch in his history, but by examining their loci, thereby making the Lazarusian notion of the unnameable name come to the fore. In other words, if we turn to Lazarus' nominal anthropology, time is not necessary. History becomes a mode in which singularities appear, and they appear not as heterogeneous multiplicities but as homogeneous multiplicities. ${ }^{30}$

Bloch's problem, according to Lazarus, is that he has collapsed the distinction between the loci (les lieux du nom) of the name and the name itself. The name, as we saw, is a polysemy because it has many possible meanings, and hence it is ultimately unnameable. But if we are to think the name "politics" in the locus of our interior subjectivities and as having taken place, we then preserve the distinction between the thing that is unnameably named and our subjective thinking about that thing. We do not lapse into a traditionally objectivist treatment of politics. But the locus of the name, that is, the subjective interiority of the name, is something that is peculiar to human subjectivity. The singular thought or intellectuality that takes place in our subjective interiority can be thought. Thinking recognizes homogeneous multiplicity, and we shall see how this is achieved for Lazarus when we look at his analysis of the French Revolution.

But this peculiar form of thinking an intellectuality intelligibly in our own human subjectivity allows us to at least designate the name though it remains unnameable. Not only can we designate it but we can also discuss it. Moreover, this thinking about the intellectual and political singularity is not a fictio mentis. It is real and concrete because it draws upon a real historic event. The Gulf War is not a political fiction. It happened or it took place (il a eu lieu) and we are still dealing with its 
political and historical consequences today. What emerges in thought, says Lazarus, is a multiplicity, but the multiplicity is homogeneous. Homogeneous should not be understood as collapsing the intellectual singularity housed in our subjectivity into a relation of identity. All that is presented in the multiplicity should not be considered to be identical.

Lazarus maintains that if we examine the historical mode of various political events, a certain consistency emerges. The consistency emerges in our subjectivity as stemming from the multiplicity itself taking place historically and having a place in our own subjectivity. That is, the consistency of the singularity that appears in our subjectivity as having taken place and as being housed in our interiority has a consistency even though it is multiple. ${ }^{31}$ The Gulf War of 1991, though multiple in definitions and contents, does contain within itself a certain consistency. But what does this mean? It means that the Gulf War is intelligible as the Gulf War that took place in 1991 and not in 1234, and that it includes certain political movements and not others. This is evidenced when we think about it as an intellectual singularity en intériorité. Its singularity consists in the fact that it is not reducible to other historical events. The Gulf War is not the Coronation of Charlemagne and its political significance does not include, for example, a politics of Teutonic hegemony. Moreover, the politics emerging from the historical events surrounding Charlemagne and the Gulf War of 1991 are not merely subjective imaginings or fictions. They are external realities upon which the subjective mind can turn and think but in no way can create absolute. The category of Blochian time is abolished for Lazarus because time is not conceived as an operator or distributor that makes history possible and the category of politics does not need time as an operator to be investigated in its historical mode. The homogeneous multiplicity does not stem from time itself but from the unnameable name that comes to appear in thought. But that multiplicity is thinkable precisely because there is a consistency in it. This consistency or homogeneity, however, is not to be identified with the unnameable name itself. Rather, it emerges only through the named event or reality having taken place. The having taken place of historical events allows one to think politics concretely, and the fact that one can think the name that is politics in the locus of one's subjectivity en interiorité reveals a possible homogeneity that is transmittable or able to be investigated. For Bloch, when time is defined as an operator that yields a heterogeneous multiplicity, any type of scientific investigation, including an historical investigation, becomes multiply differentiating. Any kind of enduring investigative results 
become impossible. At this point, it would be wise to give an example of what a Lazarusian non-Blochian view of time is. Let us turn to the example of thinking the political category that emerges when we examine the French Revolution in its historical mode.

\section{An Example: Thinking the French Revolution Politically}

In his essay, "A-propos de la politique et de la terreur," ${ }^{2}$ Lazarus gives us a concrete example of what it is to think through the name of politics and what it is to think through the revolutionary mode of politics. The French Revolution, as most people would commonsensically concede, is an historical event of the $18^{\text {th }}$ Century. This means two things. First, that the French Revolution took place (a eu lieu) and, second, that it can be thought in the locus (a lieu) of our subjectivity as an intellectual singularity. As such, this event can be thought in its historical mode, albeit to think through the French Revolution in its historical mode presents certain problems-problems that belong to the homogeneous multiplicity. ${ }^{33}$ The first problem is that the French Revolution occurs before the emergence of the category of history as we know it, that is, the science of modern history. The second problem is that it occurs prior to society's own consciousness of society being historical. It is Hegel who raised history to its full objective and cultural significance, and our very own consciousness of being historical and as emerging in history as subjects first comes to be through Hegel's writing on history. ${ }^{34}$ Given the fact that modern historiography follows the event of the French Revolution, Lazarus believes that one must deal with various historiographies in order to think through the name of the political that appears in the historical mode of the French Revolution. In other words, Lazarus can never escape his own received legacy of historical criticism and historiography, which is profoundly modern in structure. "C'estpar conséquent de l'intérieur même de l'historiographie, de son érudition, et de ses thèses adverses les unes aux autres, que je voudrais ici développer mon propos." ${ }^{35}$ It seems that Lazarus himself is stuck in a certain historical time, and he is conscious of his dilemma, and yet it is inescapable. One thinks in one's historical context, in one's time and place.

We are immediately faced with a serious problem in Lazarus' thought. On one hand, he acknowledges that he is fixed within the historiographies of his time, which implies an awareness of time understood as history. Indeed, he wishes to think from within such received historiographies. On the other hand, Lazarus will claim that 
time is a category that must be abolished. Unlike Blochian history, Lazarusian history is not conceived in temporal terms. Again, history is a mode of being, that is, the way a certain intellectual singularity comes to appear in a certain sequence insofar as that intellectual singularity is both part of the sequence and differentiated from every other singularity in that sequence. History must not be thought as mere chronology, that is, as living in a certain epoch. For Lazarus and for Bloch, history is the examination of the interior life and the mental states of the subject. Bloch, however, sees that as conditioned by time, whereas Lazarus sees it more as a category of being in relation with other singularities in a sequence of thought. For Lazarus, then, to think the singularity of the French Revolution "within" the context of historiography is not to think temporally. That is, the French Revolution is not an event that should be regarded simply as unfolding in a chronological fashion based on the flow and precipitation of certain events. Rather, the French Revolution must be thought in terms of the mental life of the subjective and what it means for it to be such. Also, the subjective in question was that of the participants, especially of those intellectuals who expressed it most clearly (Lazarus is particularly keen on Saint-Just.) In this sense, both Lazarus and Badiou insist that modes of politics can only be apprehended through the thought of the participants. Hence, his insistence, for example, on reading and thinking about what Saint Just says.

Given this position, Lazarus wishes to read the event of the French Revolution in a particular fashion. He will focus on two specific elements: the study of the political capacity of the French Revolution and, second, from this perspective, a study of terror. ${ }^{36}$ Lazarus distinguishes his project from that of a causal historiography. ${ }^{37}$ Lazarus looks to thinkers like Furet ${ }^{38}$, whose revisionist historical treatment of the French Revolution resulted, according to Lazarus, in a reduction of politics to the object of the state, in order to prove his point. Furet, drawing from and responding to Marx, ends up depriving the French Revolution of any of its political significance. It is reduced to an historical process. $^{39}$

Lazarus is confined to a certain type of historiography, but he distinguishes himself from other revisionist and "objectifying" historians by claiming that he necessarily has recourse to history and to historians, but that he wants to work from within the analyses of the historians themselves as opposed to the objective events that the historians are investigating. ${ }^{40}$ 


\section{ANTONIO CALCAGNO}

Thus far, Lazarus has claimed that the French Revolution is an historical happening, even though it happened before the formal category of history as a modern science emerged. Historiographies exist about the French Revolution. Lazarus wishes to think within given singular historiographies in order to think through the political mode of the Revolution. Ultimately, Lazarus will show that such historiographies themselves are political. He will do this by focusing on various aspects of the historiographies themselves, including the dating of the Revolution. ${ }^{41}$

Lazarus gives examples of various historians who have tried to date the French Revolution. ${ }^{42}$ The beginning and the end of the revolution are questionable. He gives the example of Aulard, who was given the Chair of the History of the French Revolution at La Sorbonne. In his book, Histoire politique de la Révolution française, Aulard concluded that the Revolution was "achieved" (s'achève) in $1804 .{ }^{43}$ According to Lazarus' reading of Aulard, this is because certain republican conditions were achieved in that year. Aulard breaks the Revolution down into various periods, starting with 1789-1792 (constitutional monarchy) and ending with 1799-1804 (plebiscite republic). This chronology is punctuated by the periods of a democratic republic and a bourgeois republic. Lazarus claims that Aulard is not simply giving an objective history of the Revolution. Aulard is seen by Lazarus as giving the French Revolution a political significance in that the French Revolution is understood as an evolution of various forms of government and various forms of the state, ultimately paving the way for the plebiscite republic. Lazarus describes the plebiscite republic as being Aulard's view of the desirable political state. Aulard, according to Lazarus, operates within the framework of an "architectonique à la Montesquieu." "Like Montesquieu, who gives a description of various political forms, Aulard is read in much the same light. Lazarus goes on to give other examples of revolutionary historiographies, including those of Mathiez ${ }^{45}$, Chateaubriand ${ }^{46}$ and Lefebvre. ${ }^{47}$ Though space does not permit a formal examination of each of these historiographies, we can see that such political readings of historiographies demonstrate the singularity of the French Revolution as a name that can reveal various modes of politics. At the same time that we can think, and therefore name, the French Revolution as a singular event that took place, its meanings are never fixed or absolute. In this sense, the French Revolution also remains unnameable.

In his analysis of the historiographies of the Revolution, 
Lazarus discovers that politics comes to the fore. The Revolution itself is not only an historical event, but thinking about the Revolution itself becomes political. Lazarus himself offers his own historiographical reading such that the singularity of the French Revolution is seen in an historical mode but it is also seen as showing forth the politics folded into this very same thinking about the French Revolution. Having shown how politics comes to the fore in thinking about the historical modes of the French Revolution as espoused by various thinkers, Lazarus claims that the politics he sees as emerging from the French Revolution is a revolutionary mode of politics, and this is in contradistinction to Aulard, who sees a delineation of various forms of political organization that lead to a plebiscite republic. ${ }^{48}$ More precisely, he sees this mode coming to show itself in the sequence that extends from 10 August 1792 to July 1794. "[Elle-la Révolution] est identifiée par les lieux suivants: Convention, société sans-culottes, clubs, armées de l'an II."49 For Lazarus, the revolutionary mode finds its apex in the singularity of Saint-Just. ${ }^{50}$ Lazarus goes on to describe in detail what he sees to be the precise content of the revolutionary mode, including an inescapable terror of Robespierre, the role/fate of Louis XVI, national representation and ultimately the laws and principles of a revolutionary government (e.g., Saint-Just). To go into detail at this point would be to distract us from our central concern about Lazarus' claim about time. It is this claim that we would like to focus on. We believe we have enough information about Lazarus' project that we can now critique Lazarus' claim concerning the abolishment of the category of time and whether this is viable or even possible.

\section{Can the Category of Time Be Abolished?}

Lazarus claims to show us how in the analysis of the unnameable name called "politics" modo historico a discussion of the singularity of an intellectuality can emerge, but only if we abolish the category of Blochian time and its heterogeneous multiplication of meanings. Lazarus' critique of Bloch demonstrates that a science called history would be unthinkable because of the heterogeneous multiplication of Blochian meanings that would emerge. It would appear that Bloch is closer to Derrida in that there is a certain impossibility that colors Bloch's project, an impossibility that would contradict the possibility that Bloch sees in his analysis of enduring singular historical events. But this seeming affinity between Bloch and Derrida is just that, namely, a mere appearance. Though both thinkers wish to make 


\section{ANTONIO CALCAGNO}

space for the richness of multiple meanings that are "within" historical and political events, Bloch does not structure possibility within a double bind structure as does Derrida. The Derridean undecidability that flows from the uncontainable richness of multiple meanings of political and historical events is constituted in the double bind of the to come and the differance of a communicative flow. Though Blochian multiplicity itself suggests a differentiation of meanings, the very classification of this flow as heterogeneous makes meanings inaccessible or simply impossible to be thought, whereas Derrida would wish to have the meanings of political and historical events temporally structured by possibility and impossibility. For Derrida, meaning is possible, but it is impossible to bring it to full presence.

Lazarus' alternative of a homogeneous multiplicity allows for the thinking of an intellectual singularity as well as for the multiplicity of definitions and contents. The Lazarusian language of an unnameable name conveys the same force as Derridean undecidability stemming from the simultaneous playing out of possibility and impossibility. Ultimately, can Lazarus make the claims he does without giving some account of time?

Though Lazarus' rejection of the Blochian category of time as a heterogeneous multiplier of meanings can be seen to be valid, can thought as pensée en intériorité make do without any concept of time? The answer to this question is no. A certain sequencing still happens in thought, albeit a sequencing that is externally given in history. Events follow from each other in a certain chronology, and it could be said that the elements in the sequence may affect one another and continue to do so. Within the name "French Revolution," for example, one cannot say that the King was executed in 1792. The elements within each sequence do have a temporal order as well.

But even if we were to follow both Bloch's and Lazarus' lead and claim that such chronicling is not all-defining of the subjective or interior sense of political thought, we are still left with the problem of the subjective intelligibility/interpretation of sequencing. In his article, "Dates and Destiny: Deleuze and Hegel", Jay Lampert remarks,

A date marks a historical event in two ways. It assigns a singular moment to an event, and it situates events in a common era. The first function of the date gives the event a determinate location relative to other past events and to the present; the second makes all events available at once to memory and to interpretation. The first posits events 
in succession; the second posits them in their temporal coexistence. Both of these functions of the date are clearly genuine phenomena. But insofar as we consider events in their contemporaneity, their meaning as events in succession has been removed. ${ }^{51}$

In bringing together the thought of Deleuze and Hegel, Lampert shows how contemporaneity and succession relate. But for Lazarus, the dating or sequencing happens not because of the event itself, but because of the having taken place of the event and its occupying a place in subjectivity. This distanciation, according to Lazarus, allows one to think a given sequence in its interiority as its own singular thought. This distanciation allows a certain identification or naming of the unnameable political event in its historical mode. But is not localization or sequencing merely dating insofar as a certain ordering of events plays itself out? Even if localization permits a non-identification with the unnameable name or the "thing" that is exterior to thought, thereby preserving its unnameability, one does not erase the problem of sequencing and how it implies, as Lampert rightly points out, a certain temporal sequencing.

In his article, Lampert makes the convincing case that dating something is determined by its destiny. Lampert also takes seriously the Deleuzian claim of the radical variability of dates, noting that dates are not non-successive but differential. Lampert succeeds in pulling together a theory of the date based on his reading of Deleuze's Mille Plateaux. ${ }^{52}$ What makes dating even more variable and anarchic is the Deleuzian rhizome. If we apply Lampert's and Deleuze's view of dating events, especially as events draw from their fundamental linguistic articulation as mots d'ordre, to the Lazarusian position, Lazarusian interior sequencing comes into question. The radical consequence of Lampert's and Deleuze's position is that events appear in varied and differentiated sequences. Hence, Lenin can continue to say that the Revolution is "now." It would seem that a singular sequence, even if articulated in interior thought, would be impossible as a singularity would be continually undone by the variability and differentialization that happens in any sequencing of events. Lazarus would not deny this reality. He recognizes the radical variability and differentialization in that he describes the singular as unnameable as well as nameable. Singularities are unnameable because of the radical multiplicity and polysemy of definitions that are folded within. Yet, and at the same time, the singularity that emerges in this multiplicity and variation is nameable 


\section{ANTONIO CALCAGNO}

because it is thought; naming a singularity is possible and necessary because of intellectual work. Previously, we have seen how Lazarus names the political mode of French Revolution a "revolutionary." Something nameable emerged with the rise of the unique singularity of an event, but it can never be brought to full presence and it can never be fully named. The sequencing of historical events implies a certain dating and, therefore, a certain timing. This sequencing is vital if one wishes to name the political modes that emerge from a certain sequence of historical events as evidenced by Lazarus' naming of the revolutionary mode of politics in the historical event called, "The French Revolution". Lazarus cannot escape time altogether en intériorité and he cannot abolish the category of time.

For both Badiou and Lazarus, politics does not always exist; it is rare. Both urge us to think politics, either as an event or as a mode. What is novel about Lazarus' thought is that he sketches a profound way to think politics from within. The implications for revolutionary thought in particular and politics in general is twofold. First, Lazarus provides a profound critique of our pragmatist-liberal approach to politics. We assume that democracy and individual rights, always tied in with a capitalist economy, is our common base of understanding and the very framework within which we do politics. Lazarus asks us to dig deeper and question this very mode of liberal political economy. How does its sequence arise within us and our collective thoughts? We simply take it for granted, especially in Western politics, that it is the only way and common sense way of doing and thinking politics. Second, Lazarus gives us a concrete method to think politics from within. His nominal anthropology brings to the fore the fact that politics, what we today might call political theory, is not merely ancillary but pivotal and central. Both Badiou and Lazarus want a revolutionary mode of politics, which militantly calls for a deep thinking of the nature of the political and how it appears and works. Thinking is foundational in this respect.

I have tried to show that Lazarus cannot abolish time. Badiou is right to remark that time is central, emerging with the decisive intervention that brings about both the subject and the event. We have not only a revolutionary mode of politics but we have a time of the French Revolution that is singular. Though time may not be immediately or fully present in consciousness or thought, it still operates and is foundational, perhaps not in the transcendental sense of phenomenology, but certainly in a deep existential and historical way. Not having a category of time in thought runs the risk of Lazarus 


\section{ABOLISHING TIME AND HISTORY}

lapsing into a kind of atemporality that does not yield enough credence and recognition of temporal factors, including history, economy, culture, etc. This is precisely what Horkheimer, Adorno and the critical theorists tried to show was lacking in philosophy. This is what Badiou tried to show is indispensable about politics, namely, the subjective political time that is enfolded in all events or what Lazarus would call "sequences." 53

King's University College at the University of Western Ontario

\section{Notes}

${ }^{1}$ Here, one is reminded of the Heideggerian es gibt or the Levinasian ily $a$.

${ }^{2}$ S. Lazarus, L'anthropologie du nom. (Paris: Seuil, 1996), p. 65.

${ }^{3}$ Badiou moves from an earlier notion of periodization to a notion of sequencing in his later works.

${ }^{4}$ Lazarus, L'anthropologie du nom, p. 16.

${ }^{5}$ Ibid., pp. 16-17.

${ }^{6} \mathrm{~A}$ Deleuzian might object and say that the dating of such events is not so fixed. But for Lazarus, the content of such events is irreducible to the historical time in which they happened, although we can keep referring to the events, bringing forth new meanings. See Jay Lampert, "Dates and Destiny: Deleuze and Hegel" in Journal of the British Society for Phenomenology vol. 33, no. 2, May 2002, 206-220. More will be said about this later.

${ }^{7}$ S. Lazarus, "Anthropologie ouvrière et enquêtes d'usine: états des lieux et problématique" in Ethnologie française, vol. 37, 2001/2, pp. 385-400.

${ }^{8}$ J.-F. Lyotard, Instructions païennes (Paris: Galilée, 1977).

${ }^{9} \mathrm{~L}$. Ferry, 'La littérature sinistrée: Entretien avec le Ministre de l'Éducation National" in Le Figaro Littéraire. 10/04/2003.

${ }^{10}$ L'anthropologie du nom., p. 66.

${ }^{11}$ Ibid., p. 66.

${ }^{12}$ Ibid., p. 52.

${ }^{13}$ Ibid., p. 42.

${ }^{14}$ Ibid., p. 90.

${ }^{15}$ Ibid., p. 89.

${ }^{16}$ Lazarus says the names French Revolution, Bolshevik Revolution, and Maoist Revolution, for example, each contain a peculiarity that distinguishes them as different from one another, even though they all took place within the context of the state. "Voici les modes en interiorite dont lidentification est possible: - Le mode révolutionnaire, dont il est amplement question ici, et dont la séquence est 1792-1794.

—Le mode classiste, où l'histoire est la catégorie en conscience de la politique... La 


\section{ANTONIO CALCAGNO}

séquence du mode va de 1848, date du Manifeste communiste de Marx et d 'Engels, à 1871, où avec la Commune, les catégories de mouvements ouvriers de classe, ou mouvements historiques, sont épuisées.

-Le mode dialectique, où le nom propre est celui de Mao Tsé-toung...Les limites du mode dialectique sont 1928, date depublication par Mao Tsé-toung de Pourquoi le pouvoir rouge peut-il exister en Chine?, et 1958, qui marque la solde de la guerre de Corée et le moment où l'identification du socialisme dans les modalités de la guerre révolutionnaire cesse" (Ibid., pp. 90-91).

${ }^{17}$ Ibid., p. 136. 1993), pp. 84-85.

${ }^{18}$ M. Bloch, Apologie pour l'histoire ou Métier d'historien (Paris: A. Colin,

${ }^{19}$ Recall that Lazarus does not use these terms. Lazarus attempts to understand the subjective in terms of itself, rejecting the scientific 'correspondence' between subjective and objective.

${ }^{20}$ Bloch, Apologie, p. 85.

${ }^{21}$ L'anthropologie du nom., pp. 141-42.

${ }^{22}$ Ibid., pp. 142-43.

${ }^{23}$ Ibid., p. 143.

24 "Investigation du subjectif $d u$ dedans et du dehors, l'bistoire est alors la science des 'hommes dans le temps'. Le temps sera la catégorie polysémique, autorisant le passage du dedans au dehors et du dehors au dedans. C'est la notion de durée qui permet ce passage. La durée est l'inscription dans le temps des phénomènes et des processus. On peut la concevoir soit comme une qualité des phénomènes (certains sont brefs, d'autres longs), soit comme le compte temporel des phénomènes. C'est donc une catégorie qui opère du dedans et du dehors" (Ibid., p. 143).

${ }^{25}$ Ibid.

${ }^{26}$ Apologie pour l'histoire, p. 144.

27 "Après avoir désigné le temps comme intellegibilité, Bloch en fait une catégorie régie par l'unité des contraires et fracture le temps, qui devient à la fois continu et changeant. Que le temps soit continu et changeant installe la polysémie et conduit cette catégorie fondatrice à se donner dans une multiplicité hétérogène. Celle-ci est une multiplicité, qui reconvoque sous une même appellation (le temps) le subjectif indexé à autre chose qu'à lui-même; et une polysémie en ce que cette multiplicité est elle-même et une autre" (L'anthropologie du nom., p. 143).

${ }^{28}$ Bloch's view of science can certainly be challenged, but this would take us away from our main focus, which is Lazarus.

${ }^{29}$ Apologie pour l'bistoire, p. 144.

${ }^{30}$ L'anthropologie du nom, p. 157.

${ }^{31}$ Ibid., p. 157.

${ }^{32}$ S. Lazarus, "A-propos de la politique et de la terreur," in C. Kintzler and H. Rizk, eds. La République et la terreur (Paris: Kimé, 1995), pp. 65-87.

${ }^{33}$ Ibid., p. 65.

${ }^{34}$ It should be noted, and this Lazarus does not discuss, that Hegel 


\section{ABOLISHING TIME AND HISTORY}

says history also comes to be through the French Revolution. See Hegel's The Philosophy of History. Trans. J. Sibree (Toronto: Dover Publications, 1956), pp. $447 \mathrm{ff}$.

35 “A-propos de la politique,” p. 66.

${ }^{36}$ Ibid., p. 66.

${ }^{37}$ Ibid., p. 66. It should be noted that there is a similarity between the thought of Jacques Rancière and Lazarus in that both authors believe that history can aid in thinking through the various political "names" that emerge with various political events. In Les mots de l'histoire (Paris: Seuil, 1992), especially in the essay, "Une histoire hérétique?,” Rancière argues that a certain intelligibility of mentalities emerges in and through history (p. 177ff.). Like Lazarus, Rancière believes that a certain thinking of the intelligibility of the multiplicity of events is possible. But for Rancière, rather than doing it anthropologically, he proposes an aesthetic reading of history such that historical events like the French Revolution can be studied for their political senses through a study of various literary procedures_la poétique du savoir. "Une telle étude relève de ce que j'ai choisi d'appeler une poétque du savoir: étude de l'ensemble des procédures littéraires par lesquelles un discours se soustrait à la littérature, se donne un statut de science et le signifie." (p. 21)

${ }^{38}$ F. Furet and C. Lucien, eds. Marx et la Révolution française suivi de textes de Karl Marx (Paris: Flammarion, 1988).

39 "A-propos de la politique," pp. 67-8.

${ }^{40}$ Ibid., p. 68.

${ }^{41}$ Ibid., p. 68.

${ }^{42}$ Ibid., pp. 69-73.

${ }^{43}$ F.A. Aulard, Histoire politique de la Révolution française: origines et déveoppement de la démocratie et de la République 1789-1804 (Paris: A. Colin, 1926).

44 "A-propos de la politique," p. 70.

${ }^{45}$ A. Mathiez, La Révolution française (Paris: A, Colin, 1963).

${ }^{46}$ F.R. Chateaubriand, Mémoires d'outre tombe (Paris: Gallimard, 1986).

${ }^{47}$ G. Lefebvre, La Révolution française (Paris: PUF, 1963). Lazarus sees Mathiez as ultimately advocating a view of the revolution that introduces the category of a "possible egalitarian revolution" (p. 71). Lefebvre, against Mathiez, argues that the Revolution was started by aristocrats and ended very much in an aristocratic fashion with the reinforcement of distinctions, including aristocrat and non-aristocrat, revolutionary and non-revolutionary (pp. 71-2). For Chateaubriand the Revolution is not continuous. It consists of three different parts that have nothing in common: Republic, Empire and Restoration (p. 72).

48 “A-propos de la politique," p. 73.

${ }^{49}$ Ibid., p. 73.

${ }^{50}$ Ibid., p. 73.

${ }^{51}$ In Journal of the British Society for Phenomenology, vol. 33, no. 2, May 


\section{ANTONIO CALCAGNO}

2002, p. 206.

${ }^{52}$ G. Deleuze, Mille Plateaux (Paris: Minuit, 1980).

${ }^{53} \mathrm{I}$ am deeply indebted to this journal's anonymous readers who read my essay. Their comments were invaluable and most appreciated. I am grateful and thank them for all their help and suggestions. 